\title{
Ethnicity and Estate: The Galician Jacquerie and the Rwandan Genocide Compared
}

\author{
Tomasz Kamusella* \\ University of St. Andrews, Scotland, UK \\ ${ }^{*}$ Corresponding author. Email: tdk2@st-andrews.ac.uk
}

\begin{abstract}
In national historiography, estate (social) divisions are typically disregarded in favor of supposedly shared ethnicity, which is proposed to have united a given nation for centuries. Hence, the Polish national historiography is unable to account for the Galician Jacquerie (1846), when serfs were killing nobles, despite their (retroactively) assumed shared Polish ethnicity. On the other hand, the 1994 mass massacre of the Tutsis by Hutus is recognized as the Rwandan Genocide, though both groups share the same language, culture, and religion-or what is usually understood as ethnicity. What has sundered the Tutsis and the Hutus is the estate-like socioeconomic difference, or a memory thereof. It appears that under certain conditions estate (social, class) difference may become an ethnic boundary. In the case of the aforementioned jacquerie, the estate difference made the serfs and the nobles into two different de facto ethnic groups. Similarly, in Rwanda, estate (social) difference is implicitly posed as ethnicity, thus making the Hutus and the Tutsis into separate ethnic groups. However, the official definition of genocide as adopted by the United Nations explicitly excludes social groups (for instance, estates) from its purview, leading to terminological paradoxes.
\end{abstract}

Keywords: estate; ethnicity; Galician Jacquerie; microethnic group; nationalism; Rwandan Genocide; society of estates; Ständegesellschaft

\section{Introduction}

As a contribution to the history of ideas, methodology, and, more broadly, the "archeology of knowledge" (Foucault 1972), this article discusses the concepts of social and ethnic difference. The focus is on the observed practices of the use of such terms in Western thought and academia. During the last three decades, I have researched and lectured on the history of central Europe's national movements that are predominantly ethnic (or more specifically, ethnolinguistic) in their character. Then, in the course of the last ten years, when I have begun teaching and probing into the issues of genocide and ethnic cleansing, I realized that the example of the Rwandan Genocide poses a rarely noticed methodological conundrum.

Nowadays, the international community unequivocally recognizes the mass killings of Rwanda's Tutsis by Hutus in 1994 as a genocide. The UN Convention on the Prevention and Punishment of the Crime of Genocide offers the legal basis for this formal recognition. The Convention states that any "acts committed with intent to destroy, in whole or in part, a national, ethnical, racial or religious group" constitute a genocide (United Nations Human Rights 1948, art. 2). Yet, as discussed further, the Tutsis and the Hutus do not appear to be good examples of ethnic or racial groups as commonly understood in the Western scholarly, legal, or intellectual tradition. These two main groups of Rwanda's population share the same language, race (that is, a trait stereotypically

\footnotetext{
(C) The Author(s), 2021. Published by Cambridge University Press on behalf of Association for the Study of Nationalities. This is an Open Access article, distributed under the terms of the Creative Commons Attribution licence (http://creativecommons.org/licenses/by/4.0/), which permits unrestricted re-use, distribution, and reproduction in any medium, provided the original work is properly cited.
} 
defined through skin color), ${ }^{1}$ religion, history, and customs (Bukuru 2015, 95; Záhořík 2012, 82-83, 87-91). In addition, members of both groups live together in towns, villages, and cities. In Rwanda there are not any territories or zones that would be overwhelmingly Tutsi or Hutu, as also proven by maps with the numbers of the 1994 Genocide victims (cf. University of Minnesota n.d.) that overlap with maps of population density (cf. Madsen 2011). From the perspective of Western scholarship, the cleavage between the Tutsis and the Hutus is purely social (or socioeconomic) in its character. Until the independence of Rwanda, the Tutsis were equated with the upper stratum of Rwandan society, while the Hutus with the lower stratum.

It was the German and Belgian colonizers who administratively dubbed (thus, constructed and imposed from above) this social difference as "ethnic and racial" in paperwork and statistics, including personal identity documents and school textbooks (Mamdani 2001, 101-102; Vervust 2012, 103-105). Independent Rwanda took over this racializing and ethnicizing colonial approach to the country's salient social difference. If anything, this difference became even more politicized and immutable (Mamdani 2001, 98-99). Postcolonial Rwanda's almost invariably Hutu-dominated governments gradually made the state's Tutsis into the society's subaltern layer, reversing the erstwhile "pecking order" between these two groups (Záhořík 2012, 108-143). However, had the United Nations defined the Tutsis and the Hutus as social groups of the Rwandan nation (society), the aforementioned Convention would not have allowed for recognizing the 1994 bloodbath as a genocide, because this document excludes social and political groups from the legally binding definition of genocide.

Is a social group the same as an ethnic group? Should these designations be applied on the basis of research and in light of scholarly definitions? Or maybe politicians ought to have the last word in doubtful or sensitive cases. (I hope not!) In the story of the Rwandan Genocide, international politics and law-as managed or mediated by the United Nations-conditioned the near-universal perception of the Tutsis and the Hutus as separate ethnic groups in their own right. Having come to this tentative conclusion, I recollected the Galician Jacquerie of 1846, which continues to pose a serious methodological problem to the Polish national historiography and also appears to be a methodological obverse of the Tutsi-Hutu definitional question.

From the perspective of the Polish ethnolinguistic nationalism (that coalesced in the late 19th century), both the serfs (peasants) and the nobles they killed in this jacquerie were Poles, because they shared the same Catholic religion and presumably spoke the same Polish language. Yet, it is an anachronistic reading of the nonnational past that confuses instead of explains. In the mid-19th century in the Austrian Empire's western Galicia, the population was split by the politicized social difference (of estates), typical of ancien régime Europe. In this context, though allowing for a certain simplification, the serfs and the nobles belonged to different and legally unequal estates. It took a full century, or until the mid-20th century, to convince descendants of these very serfs and nobles that they were equal members of the same Polish nation. At present, in light of the Polish national master narrative, as offered in history textbooks for schools in Poland, the proposed ethnic (ethnolinguistic, national) sameness retroactively (anachronistically) erases the social (estate) difference between western Galicia's serfs and nobles, making it all but impossible to explain the causes and dynamics of the near-genocidal violence of the 1846 Jacquerie.

This article peers under the carpet of the anachronistic ethnicization of the past of modern Rwanda and retells it briefly through the lens of the Tutsi-Hutu social difference. Likewise, the confusingly anachronistic ethnicization of the events of the Galician Jacquerie is analyzed, while this jacquerie is explicated in terms of the contemporary social (estate) difference. The goal is to show how political decisions and needs impact scholarly research, including the application of supposedly neutral and objective definitions (in this case of ethnic group and social group). Such political interference may even alter the social reality (for instance, now most Tutsis and Hutus see themselves as belonging to different ethnic groups), yet it is incapable of changing the past. Hence, it is of import for researchers to be keenly aware of such political interference (or even manipulation) for the sake of avoiding anachronism, while probing into the past. On the other hand, this awareness 
helps social scientists (including historians) analyze how political interventions alter a given social reality nowadays, for instance, by redefining a social group as an ethnic group.

This article stresses the point that identifying a given human group as social or ethnic is not a simple or neutral decision. Opting for one label or the other may have real-life consequences for living people, including their understanding of the group's past. The basic guideline is to stick to definitions adopted, and to apply terms in accordance with what has been observed and recorded "in the field," without succumbing to the pressure of present-day political views or needs. This task is easier said than done because such terms of analysis, their definitions, and the methodology of their application also arise, develop, and change through time and space. Hence, an awareness of the history of methodology and of a given discipline is also indispensable. On top of that, I decided to discuss and compare a non-European (non-Western) case and a European (Western) one. Why? First, it is all too rarely done, even though such comparisons frequently yield interesting and unexpected insights. Second, the oft-proposed globalization (unification, standardization, uniformization, or westernization) of the modern world, if true, should allow for comparisons of this type. The only way to know is to embark on such an exercise. And last but not least, I believe that the new socioeconomic division between the "poor global South" and the "rich global North" should not prevent the flow of ideas between these two inseparable halves of the "late modern world."

\section{Nationalism and the Nonnational Past}

In this article the concept of social difference (and social group) is exemplified and analyzed through the lens of western and central Europe's early modern legal category of estate (état or ordro in French, or Stand in German). Nowadays, this antiquated legal concept is usually mentioned only when talking about the Third Estate (or the commoners), which was the main actor and beneficiary of the French Revolution. However, the notion of estate allows for teasing out how difference between groups of people used to be construed, organized, and legislated in early modern Europe, hence from before the emergence of nations and nation-states but across central and eastern Europe well into the 19th and even the early 20th century. In this region waning estates persisted to a degree in parallel with (mainly ethnolinguistic) nations and nation-states, which were then being created (built). Europe in this historical context means areas of the continent outside the Ottoman Empire, where the population was organized into starkly different millets, or nonterritorial and autonomous (ethno)confessional communities.

At present ethnicity is the most popular scholarly concept for referring to group difference. It can be defined as the employment of an element, or typically several elements, of culture (social reality) for construing, building, legitimizing, and maintaining a self-reproducing human group (ethnic group). The term stems from Latin ethnicus (non-Christian, pagan) as derived from the Greek word ¿ै0vos (ethnos; a people, country). Later, ethnos came to denote "a foreign, non-Greek, nonChristian people." The aforementioned group difference, that is, ethnic difference, is exemplified in this article by ethnic groups. The term "ethnic group" means a self-reproducing, cohesive collection (group) of humans built and maintained with the use of selected elements of culture (for instance, myths, religion, music, language, seen together as the phenomenon of ethnicity) as opposed to statehood (cf. Böckh 1866; Jenkins 2008, 151). In central and eastern Europe, where ethnolinguistic nationalism predominates, the collocation "ethnic group" is employed interchangeably with the term "the nation" ("human group," not "state"). Hence, this notion of "the nation," used in this text is construed as an ethnolinguistic (or ethnoconfessional) community, not as the citizenry of a given nation-state, irrespective of language, religion, or customs (that is, ethnicity).

The discussion is preceded by a brief reflection on nationalism in Europe and how this ideology was implemented in conjunction with the rise of the social sciences in the latter half of the 19th century. As a result, nations and nation-states constitute the default norm and the default kind of social reality for social scientists. It is the very "social world," which these scholars inhabit, making it hard for them to perceive the nonnational past and nonnational elements of the present in their own 
right, without almost automatically making them look "national," in accordance with this or that national master narrative. Hence, the Polish national historiography is unable to account for the Galician Jacquerie (1846), when serfs were killing nobles, despite the anachronistically assumed shared Polish ethnicity of both groups (that is, estates). On the other hand, the 1994 massacre of the Tutsis by Hutus ${ }^{2}$ is recognized as the Rwandan Genocide-that is, an event that was ethnic in its character-though both so-called ethnic groups share the same language, culture, and religion. What has sundered the Tutsis and the Hutus is the estate-like socioeconomic difference existing between these two groups (estates), or a memory thereof. The article probes into these misrepresentations and the resultant terminological and epistemic confusion. It appears that under certain conditions estate (social, class) difference may become an ethnic boundary, or a basis for constructing one. Therefore, ethnicity and social difference should not be seen as fully separate (or separable) features of the processes of human group building, maintenance, and fissure.

Social stratification is often seen as categorically different from ethnicity. This is a case of intellectual myopia induced by scholarly categories, as employed since the mid-19th century for analyzing matters social (Jenkins 2008, 56; Malešević 2004, 39-41). Such academic disciplines as sociology or political science emerged a century and half ago at (western) European universities, which had been already located in nation-states, or in nonnational polities on the cusp of being transformed into nation-states. As a result, the "natural" vantage of observance and the "normal" (normative) point of reference for practitioners of these disciplines were and still are their own nation-states. These national polities with their institutions and customs have appeared to the aforementioned practitioners as normal (civilized) or even natural. However, historically speaking, their nation-states were established quite recently, either from scratch as Belgium in 1831 and Germany in 1871, or through the overhaul of nonnational polities into nation-states, which was the case of the French Republic in 1792 or Britain. The last polity was transformed into a nation-state through a series of piecemeal reforms and politically contingent changes from the so-called Glorious Revolution of 1688 to the electoral Reform Act in 1832.

For sociologists the basic unit and subject of inquiry is "society," and for political scientists "state." The former term stems from Latin societās (fellowship, association, alliance, union, community), in turn derived from socius (associate, friend, comrade). The term "state" (polity) shares the same etymological origin with "estate," namely, the Latin word status (condition, position), in the specific meaning of Latin status [rei püblicae] (state [of the republic]). Without declaring this explicitly, when sociologists (and social scientists in general) say "society," they actually mean the nation. Likewise, political scientists (and again, social scientists as such) have in mind the concept of nation-state, when they speak of "state." Hence, again tacitly, social (class) stratification is to be observed and analyzed only within the confines of a single society (nation), typically housed in its own state, that is, in its nation-state, or a state for one nation only. While social difference (stratification) is seen as a feature pertaining to the internal organization of society (nation), in this context ethnicity is believed to be external, that is, characteristic of the separation observed among the extant societies (nations, nation-states). This manner of thinking about societies as "billiard balls"-borrowed from the discipline of international relations, whose practitioners see and treat states in this manner (Wolfers 1951, 40, 47, 60)-yielded, among others, the metaphors-cum-scholarly notions of "social cohesion" and "ethnic boundary."

The term "cohesion" stems from the New Latin neologism cohaesiō (sticking together as part of mass), which in turn was formed from co- (together) and haerēre (to cling). This term purportedly explains why a society (nation) is (or should be seen as) a single unit ("billiard ball"), or describes and even postulates to make a given society into such a "closely knit, united" (in other words, "cohesive") unit. The concept of cohesion originally emerged as part of the specialized vocabulary of natural sciences, such as physics or chemistry. In this context cohesion denoted the propensity of particles of the same substance to stick together. Sociology as a discipline originated from the early 19th-century idea that human groups are "masses" that can be analyzed and even governed with "logical" laws or the Marxist "laws of history." These laws were proposed on the model of "laws of 
natural sciences," as discovered and employed for research by physicists in relation to matter and energy. Unsurprisingly, "social physics" was an early name for sociology (Iggers 1959).

On the other hand, the notion of ethnic boundary purportedly explains what keeps societies (nations, nation-states, imagined as billiard balls) apart. It is none other but the boundary that-in a spatial, social, and metaphoric sense-separates ethnic groups from one another. The word boundary (border, frontier) is an early 17th-century neologism composed from bound (made fast as if by a band or bond) and the Latinate noun-forming suffix -ary. In 1969, the Norwegian anthropologist, Fredrik Barth (1969), proposed that ethnic groups should not be studied on their own but in the ecological context of other (neighboring) ethnic groups. Hence, apart from the question of group cohesion, also that of maintaining separation between ethnic groups needs to be addressed. For this purpose, Barth proposed the concept of "ethnic boundary." It is a product of the dynamics of intergroup interactions, namely, members of two different ethnic groups $\mathrm{X}$ and $\mathrm{Y}$, when interacting, clearly recognize one another as belonging to the other group by the way of displaying and observing the prescribed respective sets of cultural traits (ethnicity), as seen to be typical for these groups. Such an active display and observance create, legitimize, and maintain a stable separation between both groups, that is, the very ethnic boundary. Ethnic boundary may be spatial, but most often it is social in its character, members of different ethnic groups constantly sharing the same public spaces in villages, towns and cities, and marketplaces. Arguably, endogamy (ingroup marriage) is the most popular instrument of maintaining any ethnic boundary in a social sense. One can obviously cross the ethnic boundary from one group to another by ceasing to be a member of the original group and becoming an accepted member of the other group. But it is a costly process in social, economic, and psychological terms, often entailing the acquisition of a new language, a different way of living, conversion to another religion, or permanent separation from one's original family and friends.

The scholarly thinking in these terms and with the consistent use of the aforementioned categories and metaphors is reinforced by the fact that consciously or not many sociologists and political scientists have been involved in the construction, legitimation, and maintenance of their societies (nations) and states (nation-states) (cf. Hroch 1985). Their nation-state has paid them university salaries and founded their projects so that these scholars could pursue "objective" research within the limits of this essentially national in its character paradigm for the sake of "strengthening" (the unity of) their nation and uncovering (that is, "proving" or even constructing) its ancient pedigree and history. As a result, the intellectual and analytical limit of such research is the nation and its nation-state, when talking about the "home country" and its inhabitants. In the case of an outward gaze cast beyond one's own nation (and its nation-state), the parallel limit is the billiard ball-like international relations between nation-states, typically couched in terms of ethnic (national) differences between nations living in these nation-states.

"Scientific" findings (or often, myths with the ministerial seal of approval) of such liminally national in its character research are employed as the basis of school curricula. As a result, the national master narrative is spread among population at large and reproduced in subsequent generations. Scholars who emerged from among the ranks of a given nation's Generation 0 or Generation 1 had been born to or personally experienced (and often appreciated) the nonnational reality (cf. Bolzano 1849), which they frequently aspired to actively overhaul into an “appropriately national” reality (cf. Bluntschli 1870). Their successors from subsequent generations have not had this increasingly unique privilege of observing a nonnational (prenational) reality with their own eyes. They were born as members of an already existing nation. Furthermore, any research that transcends the national limit of accepted scholarly categories and subjects of inquiry, or even worse questions the national master narrative, is by default denigrated as "unpatriotic" and "unscientific." This unspoken but continually enforced national norm "naturalizes" the national reality at hand, making the social world beyond its limits invisible (or rather imperceptible) to the researcher and population at large educated in a nationstate (cf. Balcells 1994, 26; Hill 2008, 157). 
In addition, the national master narrative often "nationalizes" the nonnational past before a given nation (and its nation-state) was even established. This phenomenon of medievalization is typical of nationalisms in Europe (or more broadly, across Eurasia), where it is commonplace to propose seriously that nations and their nation-states have existed for a millennium or longer, even if historical documents do not evidence the existence of any nations (or nation-states) earlier than two and a half centuries ago. This should not come as a surprise, given that the very concepts of "the nation" and "nation-state" were formulated in western Europe during the latter half of the 18th century, ${ }^{3}$ before spreading to central Europe and the Americas in the 19th century (Sundhaußen 1973). However, due to the nationalizing effect of education, such anachronistic claims to the contrary are widely considered to be "the historical truth." For instance, Charlemagne is seen as a great French (not Frankish) ruler, the founding of the Holy Roman Empire in 962 is posed to be the beginning of Germany, and the 9th century realm of Greater Moravia (whose actual own name we do not even know) is seen as early Slovakia (cf. Grébert 1965; Morrissey 2003; Vogel and Halfmann 1941).

\section{Estate and Ethnicity}

Social difference is typically construed as a class, ${ }^{4}$ or socioeconomic, layer (stratum) of the population in a given country (state) (cf. Calvert 1982). Classes (layers, strata) of this kind are rarely formalized, let alone legislated, in the modern world, with some rare exceptions of totalitarian or authoritarian polities, whose ideologies may require such a formalization (for instance, as in wartime Slovakia [Ústavný zákon 1939, art. 60]). As a result, due to one's own efforts, in the process of "social advancement," a person may leave their original class for a "higher" one, usually meaning that in which members enjoy more wealth per capita. It is also possible to "move" in the opposite direction, to a "lower" class, where members are poorer. Such a "downward" movement usually happens due to unplanned exigencies in a person's life, such unemployment, serious illness, or an economically devastating divorce.

It is sociologists who tease out and define classes and their rankings on the basis of statistics and research, as driven by different theoretical models. Governments and parliaments often use their findings to pass laws with an eye to alleviating the poverty of a lower class, or for taxing an upper class's staggering wealth that has increased too much. However, no legislative or classificatory compulsion exists in this respect. What is more, sociologists may differ in their preferred typologies of social classes, or criteria employed for developing these very typologies.

In essence, the notion of "class" (that is, socioeconomic stratum or layer) is an academic construct employed in the function of a term of scholarly analysis. However, it should be borne in mind that in the Soviet Union class was a significant instrument and object of politics and legislation (Fundamentals 1963, 662-668), like estates in western and central Europe during the early modern period. The notion of class permits a scholar to analyze and describe social differences as observed in modern societies. The salient difference between "class" and "estate" is that the latter was never employed as a term of scholarly analysis beyond historical or sociohistorical descriptions of ancien régime ("feudal") societies. It was a specific type of the legally enshrined sociopolitical organization of the inhabitants in a polity, known as "society of estates" (estates of the realm), ordres de la société d'ancien régime in French, or Ständegesellschaft (Ständeordnung) in German. Furthermore, when Ständegesellschaft was the legally enshrined norm of social organization in a given polity, one was supposed to be born into a specific estate, and without the possibility of ever leaving it. The sole but rather tiny exception was the estate of clergy, which was not self-reproducing, because Catholic priests were required to observe celibacy, so they had no families. Males from other estates were expected to become priests. However, in any ancien régime polity, social mobility was an anathema, seen as an existential threat to social and political stability, which rested on the unchanging estate divisions as "given by god" and upheld by the monarch with the full force of the law. ${ }^{5}$ 
Estate and ethnicity are thought as categorically different (especially by nationally minded historians), yet one is believed to be born to "one's own" ethnic group, as one used to be born to "one's own" estate in the past. In this line of thinking, also adopted by proponents of ethnolinguistic (ethnic) nationalism, one is "naturally" unable to, or at least should not, move between ethnic groups (nations). In the context of Europe, in both cases the belief in the naturalness or normalcy of being born to an estate or ethnic group (nation) has been reinforced by the old monotheistic norm of long standing that one can be a true member (confessor) only of a single religion (Church). The compromise reached in the wake of Europe's religious wars made religion into each individual's private matter and removed the crime of "apostasy" (abandoning a religion or changing it for another) from the law books. However, unlike in Japan, in the present age of unbelief, even educated Europeans with a full understanding of the constructed character of the social reality keep maintaining that one is unable to profess more religions than one at any given time. It is hard, even for a social scientist, to unshackle oneself from the basic social norms (taboos) of a society (nation, religion, ethnic group, or estate) into which one was socialized as a child. Therefore, in today's Europe, for many it is mentally easier to believe that a person can truly belong only to a single ethnic group (nation) and cannot truly master more than a single "mother tongue" (national language) than to see these phenomena as constructs. But these are none other than products of the ingenuity of humans and their groups, to which individuals can pledge allegiance as they like, though definitively peer pressure is a strong conditioning factor.

Typically, class (social difference, estate) is seen as an intragroup feature of a society (nation, ethnic group), whereas ethnicity (ethnic boundary) is posed to be a phenomenon generated by the dynamics of intergroup relations. The Latinate prefix intra- means "on the inside, within, inside," while the cognate prefix inter- functions as a kind of preposition that denotes "between, among." But in the messy reality of social relations, humans and their groups do not need to observe the Western scholastic distinctions and nuances, usually known only to academics. When the Soviet Union was founded as a communist polity legitimized by its promise of a classless society of socioeconomic equals, aristocracy (or the top layer of the estate of nobles) and industry owners (or the top layer of the bourgeois class) were made overnight into "former people" (бывшие люди byvshyie liudi), who were to be "liquidated as a class." The Soviet security police kept an eye on surviving members and children of this "liquidated class" in order to repress them and make sure that they would be barred from any meaningful career in the Soviet Union. Many descendants were born after their class had been effectively liquidated and had never enjoyed any aristocratic or bourgeois perks (Smith 2012). As a result, the class of "former people," as defined from above by the Soviet government, was effectively made into an ethnic group. Willing or not, members of this liquidated class-turned-ethnic group were not allowed to leave it. The authorities made sure to maintain this arrangement by keeping track of the "true sociopolitical group membership" (alongside nationality) of each Soviet citizen.

A similar fate befell the Soviet Union's somewhat richer peasants, denigrated as kulaks (from Russian кулак kulak [fist], that is, a metaphor for "miser, profiteer"). Irrespective of any ethnic or regional differences, the Kremlin defined and declared them to be a "backward class," who stood in the way of achieving socialism. As in the case of the class of former people, the kulak class was earmarked for liquidation by expropriation and incarceration in the Gulag, forced labor camps. Kulaks and their descendants, who knew nothing of the "old good kulak times," were traced and persecuted until 1956. For three decades, the Soviet authorities treated kulaks as an ethnic group (Conquest 1987). Unsurprisingly, the Soviet Union (alongside Britain, Poland, and South Africa) made sure that social and political groups were excluded from the definition of genocide, as adopted by the United Nation in the 1948 Convention on the Prevention and Punishment of the Crime of Genocide. The Kremlin did not want to be held to account for the liquidation of either the former people or kulaks as classes (Feierstein 2014, 15).

Apart from overhauling social difference (class) into ethnicity (ethnic group), the Soviet authorities-cum-social alchemists also morphed the latter into the former. The Soviet Union had 
a unique name as a state, which unlike names of all other polities did not feature any geographic or ethnic reference, namely, the Union of Soviet Socialist Republics. This communist state's name indicated its distrust of ethnicity. The goal was to build a fully cohesive and classless society with no social or ethnic cleavages that could tear it apart. This planned ideal society of the utopian future was potentially universal, that is, intended for the entire humanity, should the worldwide export of revolution work. Hence, not only class (social) differences had to be liquidated but also ethnicity itself, as expressed in the form of ethnic groups, which were known as "nationalities" within the Soviet Union and as "nations" outside this polity (Fundamentals of Marxism-Leninism 1963, 676-678). Ironically, this nonethnic society that would simultaneously contain and level all the Soviet Union's ethnic variety and differences turned out to be Russian in language and customs, and its official name of the "Soviet nation" (Советская нация Sovetskaia natsiia) continued to remind one of the officially "defeated and effectively transcended nationalism" (Sinitsin 2018).

\section{Galician Jacquerie}

The Galician Jacquerie of 1846 is known rather neutrally as the galizische Bauernaufstand (Galician Peasant Uprising) in German (Memoiren 1847, 108), while in Polish the more emotionally tinted, antipeasant (antiserf) sobriquets are employed, namely, the Rzeź galicyjska (Galician Slaughter) (Tessarczyk 1848), or the Rabacja galicyjska (Galician Plunder) (Giller 1871, 204). Galicia was a crownland of the Austrian Empire, formed in 1772 from the Habsburg partition zone of Poland-Lithuania. Twelve years later, in 1784, as elsewhere in the Habsburg lands, German replaced Latin as this crownland's official language. However, Galicia's PolishLithuanian nobility stuck to writing in Polish and reading for pleasure in French. German remained official in Galicia until 1869, when it was replaced with Polish. The vast majority of the Galician population were Slavophone peasants, who professed Catholicism in the western half of Galicia, which is of concern here. They shared this faith with the local nobility. Members of both social groups had no problems with communication, since the nobility's Polish language was rather close to these illiterate peasants' Slavic dialects.

Until the third and final partition of Poland-Lithuania in 1795, the traditional estate structure of the polity's society was retained. The nobility with their right to elect the monarch was placed at the top of the social pyramid. To a degree the estate of nobles shared this elevated position with the estate of clergy (whose highest stratum was invariably composed from nobles). With the exception of Jews (that is, followers of Judaism), who were ruled in line with the privileges (and disabilities) of their autonomous status as an ethnoconfessional minority, and that of rather few burghers enjoying self-government in towns and cities, the overwhelming majority of the population was composed of peasants. Unlike in western Europe, the peasantry did not constitute a separate estate but were serfs. The system of serfdom entailed that peasants were unable to leave land on which they lived and toiled. Land belonged to noble owners who could trade it as they wished, including villages and households of serfs standing on this land. By the law serfs were required to render unpaid (free) labor to noble owners, in return for which they could cultivate small plots to provide food and minimal livelihood for their own families (Kieniewicz 1969, 7-29).

Polish-Lithuanian noble reformers realized that in order to modernize their antiquated polity the subservient position of peasantry would have to be improved, as in neighboring Prussia or the Habsburg lands (overhauled into an Austrian Empire in 1804) (Bartyś 1982; Kieniewicz 1969, 4243). But traditionalists who believed in the inviolability of the estate order, as "given by god," held the sway. Hence, in Galicia the peasants owed the subsequent improvement of their lot to the Habsburg rulers, who decreased and better regulated their serfdom duties, especially during the 1780s Josephine reforms (Rozdolski 1962, 254-255). Galicia's peasantry had no proverbial love lost for the Polish-Lithuanian king of yesteryear and preferred to express their loyalty to the emperor in

Vienna. In the wake of the French Revolution, the times were turbulent, and after the Napoleonic wars a semblance of peace and stability was reestablished in 1815 only at the Congress of Vienna. 
Yet, a mere decade and half later, in 1831-1832, the restive Polish-Lithuanian nobility staged a huge uprising against the Russian Tsar in the Russian partition zone, which contained four-fifths of the former Poland-Lithuania. Military operations spilled over to the nominally independent Free City of Cracow, which de facto was under Habsburg control and economically constituted part of Galicia. Many in Galicia feared another destructive war. However, the crownland's PolishLithuanian nobles sympathized with their kin and friends in the Russian partition zone. In their minds the possibility of reestablishing Poland-Lithuania was not far-fetched. Some still remembered the country as their own paradise lost. Among other things, serfdom made Poland-Lithuania economically and socially attractive for nobles, so in their majority the noble insurrectionists did not really consider doing away with the system of serfdom.

This lack of realism cost the noble insurrectionists any popular support they could count on receiving at least from some peasants, had serfdom been abolished. Instead, the old estate divide between the Polish-Lithuanian noble owners and "their" serfs only deepened. In Galicia, the latter looked to the Austrian emperor for help and support against the oppressive noble owners. In turn, this commonsensical reaction on the Galician peasantry's part made the nobles even more distrustful and disdainful of the serfs. Since the 16th century, Sarmatism, or the vague ideologycum-worldview of the Polish-Lithuanian nobility, hinged on the ethnicization of the estate (social) cleavage. The widely espoused myth claimed that the Poland-Lithuania's nobles stemmed from "proud and brave" Sarmatian (Iranic) warriors, while the serfs originated from the "slave-like" Slavs (Borowski 2001, 70, 172-179; Bystroń 1993, 162; Grabski 1976, 245; Maruszewski 1991, 107). In this view, the estate divide overlapped with the ethnic cleavage, however spurious. ${ }^{6}$ In addition, the Habsburg reforms diminished serfdom dues, while the modernization of land cultivation in western Europe and the Americas led to the plummeting of prices for agricultural products. On this account noble landowners experienced a dual economic stress, meaning less free (serf) labor and falling income at the unchanged level of production. Faced with this dilemma, Galician noble landowners sought to shift the loss of income onto the peasantry's shoulders by extracting ad hoc duties and unregulated work from serfs. This situation added yet another layer of mutual resentment to the old estate-cum-ethnic divide (Nie-Van-Dyk 1861, 71-72).

Because of widespread illiteracy persisting among the peasantry and due to a lack of interest in their lives, not much is known on how serfs perceived their social environs, or what they might think about the estate divide, which separated serfs from nobles. Anthropological research on this question done among serfs and free peasants elsewhere in central Europe shows that until the mid-19th century the hard limit of a typical serf's spatial mobility was his village or parish. Serfdom duties prevented peasants from roaming more widely until the abolishment of the remnants of the serfdom system, for instance, in 1848 in the case of Galicia (Kieniewicz 1969, 254-256). As a result, serfs constituted separate village and parish communities, almost as much isolated from one another as from the strange and distant world of the nobles. These serf communities de facto constituted microethnic groups, each with its own customs, history, norms, and ways of speaking (Kizwalter 1999, 21, 23; Moritsch 1991a, 31, 43; 1991b, 82; Stauter-Halsted 2001, 115-141). In the case of western Galicia, which became part of the Polish nation-state in 1918, it took over a century, well into the second half of the 20th century for that matter, to span the chasms that had separated these microethnic groups and serfs' descendants from their social betters, or nobles-turnedintelligentsia, in a quest for an ethnolinguistically defined Polish nation (cf. Łuczewski 2012; Struve 2014).

In February 1846, noble insurrectionists attempted another uprising for the sake of reestablishing Poland-Lithuania, this time in the Austrian and Prussian partition zones. In reality, this uprising achieved a degree of initial success exclusively in the Free City of Cracow. At the same time, immediately to the east of this Free City, serfs arose in an uprising of their own against the local noble landowners and their families. Serf-insurrectionists (typically denigrated in contemporary literature as "rebels" and "bandits") demanded the abolishment of serfdom and settled old scores with abusive nobles, by robbing manors, roughing up, killing, and raping nobles, their families, and 
their employees (cf. Rozdolski 1958). Around one thousand nobles and their employees lost their lives, and four hundred and seventy manors were destroyed (Jezierski and Leszczyńska 2003, 143). At the same time, serf-insurrectionists made sure to express their traditional loyalty to the Austrian emperor (Kieniewicz 1971, 162, 170). But neither was Vienna ready to tolerate this peasant uprising, which brought much opprobrium against Austria in the press of western Europe. The jacquerie was summarily suppressed and all serfdom duties reinstated (Kieniewicz 1969, 123).

Some noble insurrectionists realized that there would be no hope for their uprising of 1846, unless at least some peasants would support it. Hence, in their manifesto the insurrection's leadership promised land to peasants and the abolishment of serfdom (Kieniewicz 1969: 254). Yet, the document did not evoke any interest among the peasantry. Probably, nobles responsible for propagating the manifesto among serfs reneged on this responsibility in light of the peasant uprising. In the traditional take of the Polish national master narrative on the jacquerie, the Austrians continue to be blamed as "initiators and organizers" of the peasant uprising, though to this day no proof has been found to support this accusation (Kieniewicz 1969: 125).

More importantly, the events belie the ideologized and in essence anachronistic belief that the attacking peasants and the attacked nobles belonged to the same Polish nation. At that time, in the mid-19th century, the term "Polish nation" still meant none other but the estate natio of the PolishLithuanian nobility. The ethnic concept of the "modern Polish nation," as composed from all Catholic speakers of the Polish language, irrespective of their estate, was formulated a generation later, that is, in the last third of the 19th century. And it was only in the interwar Polish nation-state and its communist counterpart after 1945 that this concept was gradually and with much difficulty implemented on the ground (cf. Kamusella 2017). The unprecedented alliance between former noble landowners and erstwhile serfs was based on the commonality of the Catholic faith and Slavic (Polish) speech, to the exclusion of people of other religions and non-Slavic languages. Unfortunately, more often than not it was politicized anti-Semitism that was used as the ultimate sociopolitical "glue" for binding this noble-serf alliance of the Polish nation (cf. Brykczynski 2018; Porter 2002; Weeks 2006).

The centuries-old estate division between the serfs and the nobles in western Galicia made them into de facto two different ethnic groups (or even manifold more in the case of serfs' village microethnic groups). The noble ideology of Sarmatism actually ethnicized this divide, by officially declaring the former to be Slavs and the latter Iranic Sarmatians. What is, however, hardly noted and commented upon in the case of the 1846 Peasant Uprising in Galicia is the fact that the peasants managed to cross the ethnic boundaries of their own microethnic groups for the sake of confronting together the noble owners and oppressors. Otherwise, the nobles would not have had any problems to suppress opposition staged by a single microethnic group of serfs from a single village or parish.

The 19th-century uprisings of the Polish-Lithuanian nobility are the staple of the current Polish national master narrative. Much time and attention is paid in each Polish school to the 1830-1831 and 1863-1864 uprisings. But both are anachronistically labelled as "national" (narodowy), while the participants tend to be identified as the "Polish nation" (naród polski). Next to no information is given on the fact that the insurrectionists were nobles, and that almost no serfs (peasants) were included among their estate-conscious ranks. The time when serfs and nobles still constituted antagonistic ethnic groups is to be forgotten for the sake of strengthening the myth of the "centuries-long" unity of today's Polish nation. Likewise, the Galician Jacquerie must be excluded from this national master narrative because it falsifies this myth, hence the peasant uprising cannot be credibly characterized as "Polish," let alone "national." Even in communist Poland, supposedly built on the foundation of the "worker-peasant alliance" (sojusz robotniczo-chłopski), the communist authorities treaded carefully in order to not dismantle the de facto anti-Semitic Catholic nobleserf alliance around which the Polish nation had been built between the mid-19th and mid-20th centuries. To this day, no thorough monograph has been devoted to the "un-Polish and nonnational" 1846 Peasant Uprising; and the sole book-length overview of an exploratory character uses the euphemism of "peasant movement" (ruch chłopski) to refer to this uprising (Kieniewicz 
1951). In contrast, tens of monographs and hundreds of articles have been lavished on the two aforementioned "Polish national uprisings" of the 19th century that took place in 1830-1831 and $1863-1864$.

\section{Rwandan Genocide}

When the Rwandan Genocide was underway during the first half of 1994, the USA, which had finally ratified the Convention on the Prevention and Punishment of the Crime of Genocide only six years earlier (1988), made sure to not utter the feared "G-word." In light of this convention, recognizing the ongoing mass massacres as a genocide would have obliged Washington to intervene in Rwanda. This possibility was to be avoided after the 1993 debacle of the US forces in Somalia (Bowden 1999). Other members of the UN Security Council supported the USA in their stance on this matter, and thus lent much credence to the widespread accusation that in the eyes of the West and Asia "African lives are not valued" (Grünfeld and Huijboom 2007, 238). Apart from the USA, especially Britain and China, as permanent members of the Security Council, were opposed to the idea of any humanitarian intervention in Rwanda (Melvern 2000, 179-180, 210).

In press reports, and nowadays in the popular discourse, the Rwandan Genocide is portrayed as a slaughter of the minority ethnic group of Tutsis by the majoritarian ethnic group of Hutus (ReginiaZacharski 2012). More nuanced studies propose that what happened in Rwanda was a genocide of Tutsis and moderate Hutus, who tried to protect their Tutsi family members, friends, and neighbors (Fujii 2009, 15). But very few scholars and commentators remember about the fate of the Twas (Jessee 2017, 229), let alone refer to the massacres of this ethnic group's members as a "genocide." Apart from Tutsis and moderate Hutus, the Hutu génocidaires wiped out a third of the Twas, so that not a single village or settlement of Twas remains in today's Rwanda (Minority Rights Group International n.d.).

Prior to the genocide, Tutsis numbered almost six hundred thousand in Rwanda. They constituted 8.4 percent of the country's population of 7.1 million. In the course of the genocide, at least half a million lost their lives, that is, 77 percent members of this ethnic group. Immediately after the genocide, Tutsi survivors numbered about 150,000. However, in pregenocide Rwanda the state administration and offices were dominated by Hutus, who sought to deflate the number of Tutsis in Rwanda. On the other hand, the entailed anti-Tutsi discrimination caused many Tutsis to hide their identity. Hence, the actual number of Tutsis in Rwanda might be as high as eight hundred thousand before 1994. According to high estimates as many as 84 percent of Tutsis were killed during the genocide (Verpoorten 2005, 335-336). The difference between this number of murdered Tutsis, and the total one of all genocide victims, at the level of about one million (Melvern 2000,4), accounts for the slain Twas and moderate Hutus (Verwimp 2013, 57). According to the official Rwandan census data, before 1994 Hutus constituted over 91 percent of the population, while Twas constituted 0.4 percent (Verpoorten 2005, 341).

One decade after the genocide, in 2004, the Rwandan government stopped distinguishing among and collecting information on the country's "traditional" ethnic groups of Hutus, Tutsis, and Twas (Lacey 2004). In this official de-emphasizing of ethnicity, Rwanda follows the general tendency in this respect, as observed across the decolonized states in sub-Saharan Africa, each of them being highly multiethnic. In neighboring Burundi the perceived difference among the same ethnic groups of Hutus, Tutsis, and Twas had been suppressed already in the 1970s. Similarly, no statistical data was gathered or compiled on these ethnic groups (Uvin 2002, 166). ${ }^{7}$ However, in international literature, the following information is widely and quite unreflectively repeated that Hutus constitute 84 percent of Rwanda's inhabitants, Tutsi 15 percent, and Twas 1 percent (Berlatsky and Chalk 2015,22). As though the genocide did not happen, and actually the number of Tutsis has grown in Rwanda faster than those of the other ethnic groups. Likewise, international sources tend to repeat almost exactly the same statistics on these three ethnic groups in the case of Burundi (African Studies Center, n.d.). 
But do Hutus, Tutsis, and Twas constitute separate ethnic groups in their own right as conventionally understood in the social sciences and the popular Western discourse? Members of these three groups-in their own emic view (cf. Gasarabwé 1992; Nibagwire and Zorc 2002)— speak the same language and profess the same religion (Isabirye and Mahmoudi 2000, 63). The former is known as Kinyarwanda (the language of Rwanda) in Rwanda, and as Kirundi (the language of Burundi) in Burundi. Some differences between these two languages are negligible from the perspective of mutual intelligibility (Bukuru 2015, 95) and stem from the fact of different standardization choices pursued in Rwanda and Burundi, respectively (Nassenstein 2019; Zorc and Nibagwire 2007). Due to this state-based politics of language, two separate Wikipedias exist online, one written in Kinyarwanda and the other in Kirundi (Wikimedia 2020), but no bilingual Kinyarwanda-Kirundi dictionaries exist. ${ }^{8}$ In addition, Rwanda and Burundi are confessionally homogenous. Nowadays, these two countries' inhabitants invariably profess a form of Christianity, as introduced by the colonizers.

Significantly, in stark contrast to other postcolonial states in sub-Saharan Africa, both Rwanda and Burundi are quite exceptional in the de facto ethnolinguistic homogeneity of their populations (Záhorrík 2012, 8). ${ }^{9}$ In central Europe, after World War I, the prevalent belief has been that a proper ("true") nation equates all the speakers of a single language, who should be gathered in a single nation-state of their own (Kamusella 2018). From this central European perspective, all speakers of the common language of Kinyarwanda-Kirundi constitute a single nation. Many Rwandan and Burundian intellectuals also adopted this ethnolinguistic definition of the nation, but for the population within their respective country (cf. Nzabatsinda and Mitsch 1997, 99). However, to a central European ethnolinguistic nationalist it would make no sense that "the same" ethnolinguistic nation inhabits two separate states. However, such cases of the political bifurcation of a "single ethnolinguistic nation" occur in Europe, too, as in the instance of the "German-speaking nation" in the two separate states of Austria and Germany. But the existence of Hutus, Tutsis, and Twas as separate ethnic groups (nations), who speak the same language, profess the same religion, and live in the same country (either Burundi or Rwanda) would be inexplicable and even more shocking to such a central European nationalist. From the perspective of ethnolinguistic nationalism as practiced in central Europe, the absence of any (socially noticeable) linguistic and/or confessional difference entails the ethnic sameness that, as a rule of thumb, ought to yield a single ethnic group (nation), which in its entirety should be housed in a single state.

What sunders the Hutus, Tutsis, and Twas is not language or religion but socioeconomic difference. It is eerily similar to the estate difference, which used to separate Catholic serf-peasants and Catholic Polish-Lithuanian nobles in the Austrian Empire's crownland of Galicia until the mid-19th century. In the precolonial tradition, a Hutu was an agriculturalist (peasant, farmer), a Tutsi a pastoralist (cattle breeder), and a Twa a forest dweller (hunter-gatherer). This social differentiation, due to varying ways of winning livelihood, was connected to the traditional precolonial social structure. Tutsi pastoralists tended to constitute the top social stratum, elite (aristocrats, rulers, the rich). Hutu agriculturalists (laborers, serfs, the poor) accounted for the majority of the population, while the least numerous Twa hunter-gatherers formed a marginalized underclass of the poorest and least valued in the population (like Roma in today's central and eastern Europe) (Mamdani 2001, 73-75; Vervust 2012, 81; Záhořík 2012, 78). Before colonization, these social differences were not yet bureaucratically set in stone. For example, after a bumper harvest a successful Hutu farmer (comparable to a serf in Galicia) could buy a herd of cows and thus become a Tutsi (similar to a noble). Likewise, a Hutu (serf) who happened to have lost his land might be pressed by circumstances to adopt a hunting-gathering way of life, which would make him into a Twa (slave) (Záhořík 2012, 78).

Burundi and Rwanda emerged as separate states, due to their precolonial history, as separate polities ("kingdoms"). German colonialists, who claimed both countries in 1890, gradually subdued them between 1892 and 1906, with the last pockets of armed opposition extinguished by 1910 . German bureaucrats accepted the obtaining sociopolitical reality on the ground for the sake of 
establishing a working system of indirect colonial rule. Beginning in 1906, Burundi and Rwanda were administered as the Residenturen ("residencies," governorships) of Urundi and Ruanda within the German colony of German East Africa (Deutsch-Ostafrika), which at present corresponds to the two aforementioned countries and Tanzania. German colonial "residents" (that is, governors) oversaw the indigenous administration and made sure to extract "due" taxes for Berlin. During World War I, in 1916 Belgian troops from the neighboring Belgian colony of Congo occupied Urundi and Ruanda. After the war, in 1922, the League of Nations entrusted Rwanda and Burundi as a joint mandate of Ruanda-Urundi to Belgium. This arrangement prevented the Belgians from merging Rwanda and Burundi with their outright colony of Congo. Brussels ruled Ruanda-Urundi until 1962, when both Rwanda and Burundi were granted independence (Záhořík 2012, 18-65, 224).

In line with the 19th-century ideology of "civilizing mission," German and Belgian colonial administrators shared the stereotypical Western preconception that Africa was a kind of Europe at an "earlier or lower stage of development" (cf. Constantini 2006; Tylor 1865, 110; Wood 1872). Hence, they tended to interpret the social-or rather, socioeconomic-difference between Tutsi and Hutus in the "medieval" or "feudal" terms of the ancien régime social order of unequal estates. In Europe this social system of estates happened to precede the emergence modern (democratic) states of equal citizens, that is, with the same right to vote (suffrage), who enjoy the same rights and responsibilities, and above all, equality before the law. In this Eurocentric view Tutsis were none other but nobles (lords), while Hutus were perceived to be serfs (vassals) of Tutsis. In colonialists' gaze Tutsis seemed to "constitute" the first and second estates of prerevolutionary France, while the third estate was "composed" of Hutus (and Twas) (Goody 1963, 5-6; Lemarchand 1966, 593-594; Maquet 1961).

In this "medievalizing" fashion the German, and subsequently Belgian, colonizers took over the precolonial institutions of uburetwa (literally "slavery," meaning "forced labor") and ubuhake (literally "servitude," meaning a system of unequal patronage). However, uburetwa was instituted as late as 1870 . What is more, this duty was imposed only on farmers (Hutus), not on pastoralists (Tutsis). This development contributed to the standardization of the previously fluid socioeconomic distinction between these two socioeconomic groups. Subsequently, this distinction became enshrined in the local (indigenous) law, entailing the emergence of the increasingly rigid estate- or caste-like sociopolitical differences between Tutsis and Hutus. Under this system of uburetwa, in return for the tenure of arable land, Hutu agriculturalists were obliged to carry out (unpaid) menial labor on the landowner's fields or in his household. This de facto forced labor took about half of all working time of a Hutu and his family (like serfdom duties in mid-19th-century Galicia). Landowners (ubukonde, "master, owner") tended to be local potentates and administrators, either designated by the ruler (mwami, "king") or enjoying close ties with his court (Vansina 2004, 134136). At times also Tutsis were required to perform uburetwa, but they were given "noble" tasks that were not seen as "degrading." Typically, all Tutsis (rich and poor) and rich Hutus were exempted from this kind of forced labor (271-272).

The system of ubuhake was much older, having emerged at the turn of the 17th century (Vansina 2004, 47). The patron (shebuja) gave the client (umugaragu, "servant") the use of a cow, which remained the former's property. Furthermore, the shebuja extended his (sociopolitical and armed) protection over the umugaragu. In return, the client was obliged to help the patron when needed, and de facto became his servant (umuhakwa, "vassal, victim”) (Vansina 2004, 47-48; Záhořík 2012, 78). The client tended to be an agriculturalist, who would help cultivating the patron's fields for free. What is more, the umugaragu provided the shebuja with his own products without expecting any payment in return (Meeren 1969, 210). However, until the colonial period ubuhake did not consistently mark the socioeconomic distinction between pastoralists (Tutsis) and farmers (Hutus) but rather between the rich and the poor in general (Meeren 1969, 213-214; Vansina $2004,64,88$ ). Although the ubuhake contract was inheritable, it could be also dissolved, then the patron would reclaim all the cows given to the client, alongside any calves born meanwhile. On the other hand, an economically successful umugaragu could become a shebuja in his own right 
(Meeren 1969, 213, 218-219). Hence, unlike the European system of estates or serfdom, ubuhake did not prohibit or prevent social mobility.

The colonial administration took over ubuhake and uburetwa as useful instruments of indirect rule, especially for extracting revenue ("tax") from the territory. Both systems were standardized and extended all over Burundi and Rwanda (Lemarchand 1966, 600; Vervust 2012, 87; Záhořík 2012, 82). The initial German administration recast the blurry socioeconomic Tutsi-Hutu distinction between the rich and influential and the poor and marginalized as a central European-style "medieval" (or "feudal") difference between the estate of nobles (aristocracy) and the serfs (peasantry). In the interest of the colonial administration, the Tutsis were to fully control the Hutus and make sure that the latter would render free labor and dues, as required by the system of uburetwa (Lemarchand 1966, 606-607). In the spirit of the Rassenkunde ("science of race"), then quite popular in Europe and across the west, the German colonialists introduced to Rwanda and Burundi the myth that Hutus were local Bantus ("blacks"), while Tutsis supposedly stemmed from Ethiopia or even Mesopotamia. In this colonial arrangement, the latter were considered "whites," or at least "white blacks," in contrast to through and through "black" Hutus (Mamdani 2001, 79-87; Záhorrík 2012, 77). On this "scientific basis," in 1931, the trusted Belgian colonial hand, Pierre Ryckmans, authoritatively pronounced that "the Tutsis were destined to rule [over the Hutus]" (Ryckmans 1931, 26). His colonial experience and know-how eventually earned Ryckmans the coveted post of Governor-General of Belgian Congo in 1934, which he held until 1946.

The Belgians made shebujas (patrons) responsible for paying taxes, which incentivized the latter to extract more dues and labor from umugaragus (clients) in a more inflexible manner than previously (Meeren 1969, 209; Vervust 2012,96). In turn, the serfdom-like system of uburetwa was made into a regular method of "taxation" (Záhořík 2012, 81-82), in line with the widespread system of forced labor, as practiced in Belgian Congo since the 1880s (Hochschild 1999, 278). The rapid Christianization of the mandate of Urundi-Ruanda, mainly by missionaries of the Belgian Catholic Church, both justified and popularized (also through elementary education) among the population at large ("natives") the racialized-cum-ethnic way of perceiving Tutsis and Hutus as separate "races" (Záhořík 2012, 82-83, 87-91). The "rationalization" of labor and revenue extraction required bureaucratization and ubiquitous control over spatial and social movement, which led to the gradual introduction of "identity booklets" (livret d'identité in French and eenzelvigheidsboekje in Dutch) during the 1930s. The rubric for "race" (race in French and ras in Dutch) unequivocally equated it with the parallel rubric for "tribe" (peuplade in French and volksstam in Dutch). Only three preprinted choices of "race/tribe" were given, in the following order (and tacit ranking): Tutsi, Hutu, and Twa (Vervust 2012, 103-105). Colonial bureaucrats set this racialization-cumethnicization of social difference in stone by including a question about one's "race/tribe" in the colonial census of 1933-1934. Census-takers made sure to collect information about people's "races/tribes," but in many cases such a label was unilaterally imposed on confused individuals. Subsequently, one was not permitted to change one's "race/tribe" and was compelled to inherit it from one's father. In the starkly patriarchal society, mother's "race/tribe" was not passed to children. As a result of these policies, social advancement was stalled, due to this de facto ethnicization of the estate-like socioeconomic difference, especially between Hutus and Tutsis. The difference was made into a formalized cleavage, that is, an ethnic boundary (Mamdani 2001, 98-99).

Rather than being primordial or precolonial, it was the colonial policies, which made Tutsis, Hutus, and Twas into separate ethnic groups ("races/tribes") (Mamdani 2001, 101-102). In postcolonial Rwanda and Burundi, the social and bureaucratic existence of these ethnic groups was unreflectively reinforced by adopting the colonial bureaucratic system, including its classification of "races/tribes." "Not-yet-fully-civilized natives" were led to emulate the example of their former "civilized" colonizers. The postcolonial administrations of independent Rwanda and Burundi also took over the colonial identity card, which became officially known as carte d'identité in French and karita y'ibiranda umuntu, "a person's identity card," in Kinyarwanda. The rubric for 
"race/tribe" was "modernized" to that for "ethnicity," that is, ubwoko, "type, kind, sort" in Kinyarwanda, and ethnie in French (Vervust 2012, 105). In preparation for independence, the colonial administration abolished uburetwa in 1949 and replaced it with a monetary tax (Záhoŕík 2012, 82). In 1954 it was decided to dismantle the ubuhake system, which took three years, or until 1957 (Meeren 1969, 226-228). Despite these changes, in 1959, the administration (that is, the positions of chiefs and subchiefs) remained almost fully in the hands of Tutsis, with the exception of a mere 2 percent of the posts of subchiefs, which were held by (rich) Hutus (Meeren 1969, 266).

With the introduction of full suffrage, it turned out that overnight the previously dominant, ethnicized social (estate) elite of Tutsis became an ethnic minority both in independent Rwanda and Burundi. Under democratic conditions the ethnicized social group (estate) of rank-and-file Hutus emerged as the two countries' majoritarian ethnic group. In this situation ethnically based Hutu parties were posed to win each and every election, while Tutsis could hold to power either by de-ethnicizing postcolonial politics or by instituting an authoritarian regime propped by a Tutsidominated army. All these solutions were tried during different periods in Rwanda and Burundi (Vandeginste 2014). The socioeconomic difference, recast by the colonial administration as a racialized estate order, and subsequently ethnicized after decolonization, resulted in a cycle of increasingly genocide-like violence and retributions between the Hutus and Tutsis, which in 1994 culminated in the Rwandan Genocide (Záhořík 2012, 225).

\section{Conclusion}

The United Nations' Convention on the Prevention and Punishment of the Crime of Genocide defines genocide as "acts committed with intent to destroy, in whole or in part, a national, ethnical, racial or religious group" (United Nations Human Rights 1948. art. 2). The United Nations and international community officially recognized the 1994 massacres of predominantly Tutsis (alongside moderate Hutus and Twas) as a genocide because the majority of outside observers perceive Tutsis and Hutus as ethnic groups in their own right. If the same definition is applied to the case of the Galician Peasant Uprising of 1846, the outside observers-that is, today's historians and once the 19th-century European elites-would not agree that this event amounted to a genocide (or rather an attempted genocide). Leaving aside the issue of intent, serfs and nobles as parties to the conflict were and still are seen to have been social (estate) groups of the same "Polish" ethnicity rather than separate ethnic groups.

But apart from this etic (outside) perspective, it is of import to reflect on how the involved themselves would assess the events of the Galician Jacquerie from their own emic perspective. It appears that western Galicia's serfs and nobles would rather see what is nowadays defined to be social (estate) difference as an immutable-“god-given"-ethnic cleavage. Neither a serf, let alone a noble, would have dared to cross this legally enforced, centuries-old cleavage between them. Hence, to a noble's eye, who survived an onslaught staged by "his" serfs, the Galician Jacquerie was an unexpected genocidal-like event, which shockingly breached "human and god's laws." What about then Hutus and Tutsis in the precolonial times, when these socioeconomic identities (statuses) had not been yet racialized and ethnicized by colonizers? Well, to them the latter-day Rwandan Genocide would appear to be inexplicable. Should one happen to have a grudge against a rich person, one can try to become rich oneself or to settle (violently, or not) this grievance with the person concerned. The matter would be personal, not political. Hence, proposing to exterminate all the members of the entire economic and political elite in a given society would be unthinkable, unless one would have already become a communist dreaming of a worldwide revolution on the way to classless society.

Yet, it is strange to a Western (but especially central European) observer-when she has learned that neither language nor religion separates the Hutus from the Tutsis-to think about the Rwandan Genocide as a genocide. This case does not comfortably fit the Convention's definition of genocide. ${ }^{10}$ But in the case of Rwanda scholars and the world public opinion de facto accept that 
the bureaucratically racialized-cum-ethnicized social difference was employed for creating and reinforcing an ethnic cleavage, which then underpinned the 1994 Genocide. If such a counterintuitive "leap of faith" was possible in the question of how to classify the Rwandan massacres of Tutsis, a similar open-ended approach should be accorded to any reinterpretation of the Galician Peasant Uprising of 1846. Despite sharing the same religion of Catholicism and the same Slavic speech, ${ }^{11}$ the estate difference made the involved serfs and nobles, from their own (emic) perspective, into separate ethnic groups.

Real-life events tend to surprise and often challenge the established categories of legal and scholarly analysis. Hence, it is important that such categories should not be applied mechanically and unreflectively to cases from the past and present. Present-day insights may shed more light on events from the previous centuries, which are deemed inexplicable. This is the main premise of this article's comparison of the Galician Jacquerie with the Rwandan Genocide. In addition, this atypical pairing allows for transcending the methodological limitations of national historiography (prevalent especially in central and eastern Europe) and of the Eurocentric approach to the past, which shies away from comparing European (Western) cases with non-European (precolonial, colonial, postcolonial) counterparts.

Disclosures. None.

\section{Notes}

1 Obviously, race is a western sociopolitical construct for the sake of essentially arbitrary "ranking" of human groups and for declaring some groups perceived to be "naturally" better (more intelligent) than others (Bancel, David, and Thomas 2014). Between the late 19th and mid-20th century, eugenicists and scholars of Rassenkunde (the science of race) proposed that races are a product of nature (evolution) (Scheidt 1941). This so-called scientific basis, for instance, was employed to justify racialized policies as introduced in the colonies, and it was later used for carrying out the wartime Holocaust of Jews (Langbehn and Salama 2011). However, genetic and demographic research proves that all the humanity extant nowadays belongs to the single species of Homo sapiens sapiens, while any genetic difference observed in the species's genetic pool is continuous and never discrete (CavalliSforza, Menozzi and, Piazza 1996). Hence, races exist in the social sense, as states, law, or nations, not like stones, air, or trees. The former category of objects is visible only in the mind's eye to people who know these concepts and act in accordance with them. These objects are social constructs because they cannot be weighed, measured, or detected with any measuring instrument used by physicists. On the other hand, the latter category of objects have weight and sometimes length, and they are directly accessible to the senses of humans and other living organisms.

2 In literature the ethnonyms Hutus and Tutsis usually do not take the regular English "-s" ending for denoting plurality. However, in this article I do employ this ending in order to do away with the colonial (imperial) English (western) tradition of denying this kind of "European" ("civilized") plural to ("uncivilized") African "tribes."

3 Obviously, the Latin term natio (pl. nationes) is older than the concept of the nation, or the "taxonomically highest" type of human group with, nowadays, the exclusive right to its own statehood in a polity not shared with any other nation, namely, in its own nation-state. But in early modern Europe natio (that is, "nation" in English and French, Nation in German, or nacja in Polish) denoted these estates of a polity (usually, the clergy and nobility), who could legally influence politics and thus limit the monarch's power. What is more, in the late medieval period, this Latin term natio was employed at universities to speak about students as a group coming from a kingdom or a broader geographical region, irrespective of their actual ethnicity (vernacular) or religion (cf. Kemiläinen 1964, 13-18). 
4 The term "class" stems from the Latin word classis (class, rank, fleet), in turn derived from calāre (to summon). In the early modern period, the French word classe denoted "a division of the people, an assembly of people, or a body of subjects called to arms."

5 Obviously, in some rare cases, when a serf or commoner rendered an unusually useful service to a ruler, the latter could choose to ennoble the former.

6 Interestingly, this ethnicized view of the estate cleavage between serfs and nobles survives in actual social interactions to this day across rural Belarus, despite the two world wars, nationalism, and communism in the Soviet Union (Engelking 2012, 275). Obviously, Belarus is one of the post-Polish-Lithuanian states, alongside Latvia, Lithuania, Poland, and Ukraine.

7 Interestingly, after the civil war in Burundi (1993-2005), waged between the country's Hutus and Tutsis, the 2005 Constitution of Burundi provides for ethnic power sharing among these two ethnic groups, and with the guaranteed participation of Twas. Like in Rwanda, nowadays in Burundi no information on ethnicity is indicated in identity cards or population registers, nor is it gathered during censuses. Only electoral lists of candidates include the unambiguous indication of their ethnicities, as required by the ethnically defined power sharing mechanism in the country's politics (Vandeginste 2014, 267-268).

8 In the mid-20th century an effort was undertaken for melding Kinyarwanda and Kirundi into a single Kinyarwanda-Kirundi language (Barakana 1952). If successful, a bipartite language, similar in this characteristic to Serbo-Croatian, would have been created.

9 Obviously, homogeneity or heterogeneity is in the eye of the perceiver. The inhabitants of Rwanda and Burundi used to be and still are multilingual. Yet precolonial state-building and colonial policies effectively limited diversity in this regard (Nassenstein 2019, 25).

10 The same is true of the Cambodian Genocide (1975-1979), whose victims and perpetrators stemmed predominantly from the same ethnic group (nation) of Khmers, who share the same Khmer language, and profess the same religion of Buddhism (Jones 2017, 397-403). It was the United States, which referred to the massacres as "genocidal" in 1979, and then officially recognized them under the name of "Cambodian Genocide" in 1994 (Travis 2017, 373-374).

11 I use the collocation "Slavic speech," instead of "Slavic language," because in the European discourse "a language" is a written (graphically recorded) form of speech. At that time only nobles "had a language," since "their" serfs were illiterate.

\section{Bibliography}

Balcells, Albert. 1994. “An Example of the National History of a Stateless European Nation: Catalonia.” In Conceptions of National History: Proceedings of Nobel Symposium 78, edited by Erik Lönnroth, Karl Molin, and Ragnar Björk, 15-28. Berlin: Walter de Gruyter.

Bancel, Nicolas, Thomas David, and Dominic Thomas, eds. 2014. The Invention of Race: Scientific and Popular Representations. Routledge Studies in Cultural History 28. New York: Routledge.

Barakana, Gabriel. 1952. "L'unification des langues au Ruanda-Urundi." Civilisations 2 (1): 67-78.

Barth, Frederik. 1969. “Introduction.” In Ethnic Groups and Boundaries: The Social Organization of Culture Difference, edited by Frederik Barth, 9-38. Bergen: Universitetsforlaget; London: Allen \& Unwin.

Bartyś, Julian. 1982. Rzeczpospolita Pawłowska na tle reform włościańskich w Polsce w XVIII wieku. Warsaw: Iskry.

Berlatsky, Noah, and Frank Chalk. 2015. Rwanda. Genocide and Persecution. Farmington Hills, MI: Greenhaven Press.

Bluntschli, Johann Caspar. 1870. Die nationale Staatenbildung und der moderne deutsche Staat: Ein öffentlicher Vortrag. Sammlung gemeinverständlicher wissenschaftlicher Vorträge 105). Berlin: A. Charisius.

Böckh, Richard. 1866. "Die statistische Bedeutung der Volksprache als Kennzeichen der Nationalität.” Zeitschrift für Völkerpsychologie und Sprachwissenschaft 4 (3): 259-402.

Bolzano, Bernard. 1849. Über das Verhältniss der beiden Volkstämme in Böhmen: Drei Vorträge im Jahre 1816 an der Hochschule zu Prag. Vienna: Wilhelm Braumüller.

Borowski, Andrzej. 2001. Stownik sarmatyzmu: Idee, pojęcia, symbole. Cracow: Wydawnictwo Literackie.

Bowden, Mark. 1999. Black Hawk Down: A Story of Modern War. New York: Atlantic Monthly.

Brykczynski, Paul. 2018. Primed for Violence: Murder, Antisemitism, and Democratic Politics in Interwar Poland. Madison: University of Wisconsin Press. 
Bukuru, Denis. 2015. "Les aires et les dynamiques linguistiques." In Atlas des Pays du Nord-Tanganyika, edited by Alain Cazenave-Piarrot, Sylvestre Ndayirukiye, and Catherine Valton, 94-97. Marseille: IRD Éditions and Institut de recherche pour le développement.

African Studies Center. n.d. "Burundi - Ethnic Groups. In East Africa Living Encyclopedia. Philadelphia: University of Pennsylvania, African Studies Center. https://www.africa.upenn.edu/NEH/bethnic.htm. (Accessed April 25, 2020.)

Bystroń, Jan Stanisław. 1993. Dzieje obyczajów w dawnej Polsce, wiek XVI-XVIII. Vol. 1. Warsaw: Państwowy Instytut Wydawniczy.

Calvert, Peter. 1982. The Concept of Class: An Historical Introduction. Hutchinson University Library. London: Hutchinson.

Cavalli-Sforza, Luigi Luca, Paolo Menozzi, and Alberto Piazza. 1996. The History and Geography of Human Genes. Princeton, NJ: Princeton University Press.

Conquest, Robert. 1987. The Harvest of Sorrow: Soviet Collectivization and the Terror-Famine. London: Hutchinson.

Constantini, Dino. 2006. Una malattia europea: Il "nuovo discorso coloniale" francese e i suoi critici. Pisa: Edizioni PLUS.

United Nations Human Rights. 1948. "Convention on the Prevention and Punishment of the Crime of Genocide." https:// www.ohchr.org/EN/ProfessionalInterest/Pages/CrimeOfGenocide.aspx. (Accessed April 26, 2020.)

Engelking, Anna. 2012. Kołchoźnicy. Antropologiczne studium tożsamości wsi białoruskiej przełomu XX i XXI wieku. Fundacja na Rzecz Nauki Polskiej. Toruń: Wydawnictwo Naukowe Uniwersytetu Mikołaja Kopernika.

Feierstein, Daniel. 2014. Genocide as Social Practice: Reorganizing Society under the Nazis and Argentina's Military Juntas. Translated by Douglas Andrew Town. Genocide, Political Violence, Human Rights. New Brunswick, NJ: Rutgers University Press.

Foucault, Michel. 1972. The Archaeology of Knowledge. Translated by A. M. Sheridan Smith. New York: Pantheon Books. Fujii, Lee Ann. 2009. Killing Neighbors: Webs of Violence in Rwanda. Ithaca, NJ: Cornell University Press.

Fundamentals of Marxism-Leninism. 1963. Translated by Clemens Dutt. Moscow: Foreign Languages Publishing House.

Gasarabwé, Édouard. 1992. Parlons kinyarwanda - kirundi: Langue et culture. Paris: L'Harmattan.

Giller, Agaton. 1871. Historja powstania narodu polskiego w 1861-1864 r. Vol. 4. Paris: Księgarnia Luxemburgska.

Goody, Jack. 1963. "Feudalism in Africa?" The Journal of African History 4 (1): 1-18.

Grabski, Andrzej Feliks. 1976. Myśl historyczna polskiego oświecenia. Warsaw: Państwowe Wydawnictwo Naukowe.

Grébert, Arvéd. 1965. Die Slowaken und das Grossmährische Reich: Beitrag zum ethnischen Charakter Grossmährens. Munich: Matúš Černák Institut.

Grünfeld, Fred, and Anke Huijboom. 2007. The Failure to Prevent Genocide in Rwanda: The Role of Bystanders. International and Comparative Criminal Law. Leiden: Martinus Nijhof Publishers.

Hill, Christopher L. 2008. National History and the World of Nations: Capital, State, and the Rhetoric of History in Japan, France, and the United States. Durham, NC: Duke University Press.

Hochschild, Adam. 1999. King Leopold's Ghost: A Story of Greed, Terror, and Heroism in Colonial Africa. Boston: Mariner Books.

Hroch, Miroslav. 1985. Social Preconditions of National Revival in Europe: A Comparative Analysis of the Social Composition of Patriotic Groups Among the Smaller European Nations. Translated by Ben Fawkes. Cambridge: Cambridge University Press.

Iggers, Georg G. 1959. “Further Remarks about Early Uses of the Term 'Social Science.”' Journal of the History of Ideas 20 (3): 433-436.

Isabirye, Stephen B., and Kooros M. Mahmoudi. 2000. “Rwanda, Burundi, and Their 'Ethnic' Conflicts.” Ethnic Studies Review 23:62-80.

Jenkins, Richard. 2008. Rethinking Ethnicity: Arguments and Explorations. London: Sage.

Jessee, Erin. 2017. Negotiating Genocide in Rwanda: The Politics of History. Cham: Palgrave Macmillan.

Jezierski, Andrzej, and Cecylia Leszczyńska. 2003. Historia gospodarcza Polski. Warsaw: Wydawnictwo Key Text.

Jones, Adam. 2017. Genocide: A Comprehensive Introduction. London: Routledge.

Kamusella, Tomasz. 2017. The Un-Polish Poland, 1989 and the Illusion of Regained Historical Continuity. Basingstoke: Palgrave Pivot.

Kamusella, Tomasz. 2018. "Nationalism and National Languages." In The Oxford Handbook of Language Policy and Planning, edited by James W. Tollefson and Miguel Pérez-Milans, 163-182. Oxford: Oxford University Press.

Kemiläinen, Aira. 1964. Nationalism: Problems Concerning the Word, the Concept, the Classification. Studia Historica Jyväskyläensia 3. Jyväskylä: Jyväskylän Kasvatusopillinen Korkeakoulu.

Kieniewicz, Stefan. 1951. Ruch chłopski w Galicji w 1846 roku. Wrocław: Wydawnictwo Zakładu Narodowego im. Ossolińskich. Kieniewicz, Stefan. 1969. The Emancipation of the Polish Peasantry. Chicago, IL: University of Chicago Press.

Kieniewicz, Stefan. 1971. Historia Polski, 1795-1918. Warsaw: Państwowe Wydawnictwo Naukowe.

Kizwalter, Tomasz. 1999. O nowoczesności narodu: Przypadek Polski. Warsaw: Wydawnictwo Naukowe Semper.

Lacey, Mark. 2004. “A Decade After Massacres, Rwanda Outlaws Ethnicity.” New York Times, April 4, 2004. https://www. nytimes.com/2004/04/09/world/a-decade-after-massacres-rwanda-outlaws-ethnicity.html. (Accessed April 25, 2020.)

Langbehn, Volker Max, and Mohammad Salama, eds. 2011. German Colonialism: Race, the Holocaust, and Postwar Germany. New York: Columbia University Press.

Lemarchand, René. 1966. “Power and Stratification in Rwanda: A Reconsideration." Cahiers d’Études africaines 6 (24): $592-610$. 
Wikimedia: Meta-Wiki. 2020. “List of Wikipedias.” Last modified March 14, 2021. https://meta.wikimedia.org/wiki/List_of_ Wikipedias. (Accessed April 25, 2020.)

Łuczewski, Michał. 2012. Odwieczny naród. Polak i katolik w Żmiącej. Monografie Fundacji na rzecz Nauki Polskiej. Toruń: Wydawnictwo Naukowe Uniwersytetu Mikołaja Kopernika.

Madsen, Elizabeth Leahy. 2011. "Rwanda: Dramatic Uptake in Contraceptive Use Spurs Unprecedented Fertility Decline.” NewSecurityBeat, November 8, 2011, map. https://www.newsecuritybeat.org/2011/11/building-commitment-to-familyplanning-rwanda/. (Accessed January 21, 2021.)

Malešević, Siniša. 2004. The Sociology of Ethnicity. London: Sage.

Mamdani, Mahmood. 2001. When Victims Become Killers: Colonialism, Nativism, and the Genocide in Rwanda. Princeton, NJ: Princeton University Press.

Maquet, Jacques Jérôme Pierre. 1961. The Premise of Inequality in Ruanda: A Study of Political Relations in a Central African Kingdom. London: Oxford University Press for the International African Institute.

Maruszewski, Józef. 1991. Cham. Łódź: Wydawnictwo Uniwersytetu Łódzkiego.

Meeren, Antoine Jean Louis van der. 1969. “The Social System of the Banyarwanda." MPhil thesis, London University.

Melvern, Linda R. 2000. A People Betrayed: The Role of the West in Rwanda's Genocide. London: Zed Books.

Memoiren und Aktenstücke aus Galizien im Jahre 1846: Gesammelt von einem Mähren. 1847. Leipzig: Verlag von Wilhelm Englemann.

Moritsch, Andreas. 1991a. "Einleitung und Problemstellung." In Vom Ethnos zur Nationalität. Der nationale Differenzierungsprozeß am Beispiel ausgewählter Orte in Kärnten und im Burgenland, edited by Andreas Moritsch, 9-43. Wiener Beiträge zur Geschichte der Neuzeit 18. Vienna: Verlag für Geschichte und Politik; Munich: R. Oldenburg Verlag.

Moritsch, Andreas. 1991b. "Der nationale Differenzierungsprozess am Beispiel ländlicher Gemeinden Südkärnens.” In Vom Ethnos zur Nationalität. Der nationale Differenzierungsprozeß am Beispiel ausgewählter Orte in Kärnten und im Burgenland, edited by Andreas Moritsch, 44-92. Wiener Beiträge zur Geschichte der Neuzeit 18. Vienna: Verlag für Geschichte und Politik; Munich: R. Oldenburg Verlag.

Morrissey, Robert John. 2003. Charlemagne and France: A Thousand Years of Mythology. Laura Shannon Series in French Medieval Studies. Notre Dame, IN: University of Notre Dame Press.

Nassenstein, Nico. 2019. "Kinyarwanda and Kirundi: On Colonial Divisions, Discourses of National Belonging, and Language Boundaries.” Modern Africa: Politics, History and Society 7 (1): 11-40.

Nibagwire, Louise, and R. David Paul Zorc. 2002. Rwanda and Rundi (Ikinyarwanda - Ikirundi) Newspaper Reader. Springfield, VA: Dunwoody Press.

Nie-Van-Dyk [Józef Szujski]. 1861. Portrety. Lviv: Karol Wild.

Nzabatsinda, Anthère, and R. H. Mitsch. 1997. "The Aesthetics of Transcribing Orality in the Works of Alexis Kagame, Writer of Rwanda." Research in African Literatures 28 (1): 98-111.

Porter, Brian. 2002. When Nationalism Began to Hate: Imagining Modern Politics in Nineteenth-Century Poland. Oxford: Oxford University Press.

Reginia-Zacharski, Jacek. 2012. Rwanda: Wojna i ludobójstwo. Warsaw: Wydawnictwo Naukowe PWN.

Rozdolski, Roman. 1958. “Do historii 'krwawego roku' 1846.” Kwartalnik Historyczny 65 (1): 403-422.

Rozdolski, Roman. 1962. Stosunki poddańcze w dawnej Galicji. Vol. 1. Warsaw: Państwowe Wydawnictwo Naukowe.

University of Minnesota. n.d. "Rwanda: Total Deaths by Commune, 4/6/94-7/22/94" (map). Holocaust and Genocide Studies:

A Research Center of the College of Liberal Arts. https:/cla.umn.edu/chgs/holocaust-genocide-education/resource-guides/ rwanda. (Accessed January 20, 2021.)

Minority Rights Group International. n.d. “Twa.”https://minorityrights.org/minorities/twa-2/. (Accessed April 25, 2020.)

Ryckmans, Pierre. 1931. Dominer pour servir. Brussels: Librairie Albert Dewit.

Scheidt, Walter. 1941. Rassenkunde. Leipzig: Reclam.

Sinitsin, Fedor. 2018. Sovietskaia natsiia i voina. Natsional'nyi vopros v SSSR, 1933-1945. Moscow: Tsentrpoligraf.

Smith, Douglas. 2012. Former People: The Last Days of the Russian Aristocracy. London: Macmillan.

Stauter-Halsted, Keely. 2001. The Nation in the Village: The Genesis of Peasant National Identity in Austrian Poland, $1848-1914$. Ithaca, NY: Cornell University Press.

Struve, Kai. 2014. "Polish Peasants in Eastern Galicia: Indifferent to the Nation or Pillars of Polishness? National Attitudes in the Light of Józef Chałasiński’s Collection of Peasant Youth Memoirs.” Acta Poloniae Historica 109:37-59.

Sundhaußen, Holm. 1973. Der Einfluß Herderschen Ideen auf die Nationsbildung bei den Völkern der Habsburger Monarchie. Buchreihe der Südostdeutschen Historischen Kommission 27. Munich: R. Oldenburg Verlag.

Tessarczyk, Antoni. 1848. Rzeź galicyjska 1846 r. czyli Szczegółowy opis dokonanych morderstw, rozbojów i łupieztw, wraz z ważniejszemi wypadkami, jakie tym okropnym scenom towarzyszyly w związku z intrygami biórokracyi. Cracow: Drukarnia Stanisława Gieszkowskiego.

Travis, Hannibal. 2017. "Genocide by Deportation into Poverty: Western Diplomats on Ottoman Christian Killings and Expulsions, 1914-24.” In Genocide in the Ottoman Empire: Armenians, Assyrians, and Greeks, 1913-1923, edited by George N. Shirinian, 354-402. New York: Berghahn.

Tylor, Edward Burnett. 1865. Researches into the Early History of Mankind and the Development of Civilization. London: John Murray. 
Uvin, Peter. 2002. "Categorizing and Violence in Burundi and Rwanda." In Census and Identity: The Politics of Race, Ethnicity, and Language in National Censuses, edited by David Kertzer and Dominique Arel, 148-175. New Perspectives on Anthropological and Social Demography. Cambridge: Cambridge University Press. Ústavný zákon zo dňa 21. júla 1939 o ústave Slovenskej republiky. 1939. Slovenský zákonník. No. 41. https://www.upn.gov.sk/data/pdf/ustava1939.pdf. (Accessed April 20, 2020.)

Vandeginste, Stef. 2014. "Governing Ethnicity after Genocide: Ethnic Amnesia in Rwanda Versus Ethnic Power-Sharing in Burundi." Journal of Eastern African Studies 8 (2): 263-277.

Vansina, Jan. 2004. Antecedents to Modern Rwanda: The Nyiginya Kingdom. Oxford: James Currey.

Verpoorten, Marijke. 2005. "The Death Toll of the Rwandan Genocide: A Detailed Analysis for Gikongoro Province." Population: English Edition 60 (4): 331-367.

Vervust, Petra. 2012. “The Relative Importance of Ethnicity, Class and Race in Colonial Rwanda: The Cases of Prison Policies, Corvées, Taxation, Census and Identity Booklets." Journal of Belgian History 42 (4): 74-109.

Verwimp, Philip. 2013. Peasants in Power: The Political Economy of Development and Genocide in Rwanda. Dodrecht: Springer. Vogel, Paul, and Waldemar Halfmann. 1941. Das Erste Deutsche Reich (900-1648). Volk und Führer: Deutsche Geschichte für Schulen. Frankfurt am Main: M. Diesterweg.

Weeks, Theodore R. 2006. From Assimilation to Antisemitism: The "Jewish Question" in Poland, 1850-1914. DeKalb: Northern Illinois University Press.

Wolfers, Arnold. 1951. “The Pole of Power and the Pole of Indifference.” World Politics 4 (1): 39-63.

Wood, J. G. 1872. The Uncivilized Races of Men in All Countries of the World. 2 vols. Hartford: J. B. Burr and Hyde, Publishers. Záhořík, Jan. 2012. Dějiny Rwandy a Burundi. Dějiny států. Prague: Nakladatelství Lidové noviny.

Zorc, R. David Paul, and Louise Nibagwire. 2007. Kinyarwanda and Kirundi Comparative Grammar. Dunwoody Press's Bantu Languages. Hyattsville, MD: Dunwoody Press.

Cite this article: Kamusella, T. 2022. Ethnicity and Estate: The Galician Jacquerie and the Rwandan Genocide Compared. Nationalities Papers 50: 684-703, doi:10.1017/nps.2021.12 